\title{
Penyelesaian Sengketa Kontrak Modal Ventura Dengan Perusahan Pasangan Usaha (PPU)
}

\author{
Indrajaya \\ Fakultas hukum Universitas Muhammadiyah Palembang \\ Correspondence email: indrajaya.palembang@gmail.com
}

\begin{abstract}
Abstrak. Dalam menjalankan usahanya, yang sering menjadi kendala utama bagi pelaku usaha dalam mengembangkan usaha biasanya terkait dalam penyedian modal. Guna mengatasinya, Pemerintahan mengeluarkan kebijakan dibidang ekonomi, Salah satunya dengan terbitnya kebijakan tentang Lembaga Pembiayaan sebagaimana diatur dalam Peraturan Presiden Nomor 9 Tahun 2009. Ditindak lanjuti dengan Peraturan Menteri Keuangan Tentang Perusahaan Modal Ventura No. 18 Tahun 2012. Sebagai salah satu usaha dibidang jasa pembiayaan, pendekatannya tidak hanya dalam bisnis tapi juga perlu didampingan pendekatan hukum (legal approch) sehingga keberadaannya mendapat pengakuan dalam lalu lintas bisnis. Meskipun perjanjiannya sudah diikat dalam kontrak, namun masih sering terjadi adanya perusahaan pasangan usaha yang melakukan wanprestasi, bahkan berujung pada sengketa di Peradilan. Adapun tujuan penelitian ini adalah untuk menganalisis penyelesaian sengketa akibat wanprestasi yang dilakukan PPU terhadap isi kontrak pembiayaan antara Perusahaan Modal Ventur dan PPU. Metode penelitian adalah penelitian hukum normatif, menggunakan bahan hukum primer, bahan hukum sekunder dan bahan hukum tersier. Pendekatan dilakukan dengan pendekatan perundang - undangan (statute approach) dan pendekatan konseptual (conceptual approach). Dari hasil penelitian diketahui bahwa penyelesaian sengketa akibat wanprestasi yang dilakukan PPU terhadap isi kontrak pembiayaan antara Perusahaan Modal Ventur dan PPU penyelesaian sengketanya dilakukan dengan lebih mengutamakan mekanisme non litigasi, namun apabila tidak tercapai kesepakatan maka digunakan jalur Litigasi.
\end{abstract}

Kata Kunci: Penyelesaian Sengketa; Modal Ventura; Perusahan pasangan usaha

Abstract. In running their business, what is often the main obstacle for business actors in developing their business is usually related to the provision of capital. In order to overcome this, the Government issued policies in the economic sector, one of which was the issuance of policies regarding Financing Institutions as regulated in Presidential Regulation Number 9 of 2009. Followed up by the Regulation of the Minister of Finance on Venture Capital Companies No. 18 of 2012. As one of the businesses in the financial services sector, its approach is not only in business but also needs to be accompanied by a legal approach (legal approch) so that its existence can be recognized in business traffic. Even though the agreement has been bound in a contract, it is still common for business partner companies to default, and even lead to disputes in court. The purpose of this study is to analyze the settlement of disputes due to default by PPU on the contents of the financing contract between the Venture Capital Company and the PPU. The research method is normative legal research, using primary legal materials, secondary legal materials and tertiary legal materials. The approach is carried out with a statutory approach (statute approach) and a conceptual approach (conceptual approach). From the results of the research it is known that the settlement of disputes due to default by PPU on the contents of the financing contract between the Venture Capital Company and PPU, the settlement of the dispute is carried out by prioritizing non-litigation mechanisms, but if no agreement is reached, the Litigation channel is used.

Keywords: Dispute Resolution; Venture Capital; Business partnercompany

\section{PENDAHULUAN}

Pandemi Covid 19 yang saat ini terjadi secara global tidak hanya berdampak pada kondisi Kesehatan. Hal inipun berdampak pada perekonomian dunia yang mengarah pada terjadinya krisis ekonomi secara global. Hal ini tak terkecuali terjadi pada perekonomian di Indonesia.

Akibatnya pandemi ini, tingkat pertumbuhan ekonomi Indonesia dalam kuartal II-2020 mengalami krisis ekonomi yang sangat dalam hingga mencapai minus 5,32\%, kondisi ini jauh dari perkiraan semula yaitu minus 3 sampai 5 persen. Hal ini sebagaimana disampaikan oleh Menteri keuangan Sri Mulyani dalam wawancara eksklusif dengan CNBC Indonesia pada tanggal 19 Agustus 2020.

Namun demikian, tidak semua usaha kecil di Indonesia sampai mengalami "gulung tikar" karena usaha kecil saat ini banyak yang mampu dalam mempertahankan usahanya dari resesi ekonomi dengan kemandirian dan tiadanya pinjaman kredit dari perbankan yang besar ditambah dengan adanya bantuan dari Pemerintah dalam berbagai bantuan pemberian insentif kepada pelaku usaha kecil.

Dalam prakteknya, saat ini usaha kecil, mikro dan menengah meski dilindungi oleh UU NO 20 Tahun 2008. Namun dalam kenyataannya Usaha ini masih sulit berkembang, hal ini karena sulitnya usaha kecil dalam mendapatkan modal usaha dari perbankan. 
Selain itu juga kendala yang dihadapi pelaku usaha kecil adalah terkait akses manajemen yang baik, kemampuan alih teknologi dari perlengkapan kerja, adanya persaingan usaha tidak sehat oleh pengusaha besar dalam kegiatan bisnis dalam merebut pasar ${ }^{1}$.

Melihat kenyataan diatas, untuk mengurangi kesenjangan antara pengusaha kecil dan pengusaha besar dikeluarkanlah kebijakan Pemerintah dalam bidang ekonomi.

Kebijakan dalam bidang ekonomi yang diambil pemerintah dalam upaya meningkatan pembangunan dibidang ekonomi adalah dengan mengeluarkan berbagai paket regulasi kebijakan ekonomi secara nasional.

Salah satu kebijakan Pemerintah tersebut adalah dengan dikeluarkannya Keputusan Presiden yang mengatur mengenai Lembaga Pembiayaan dan pelaksaann secara teknisnya dilaksanakan dengan keputusan Menteri Keuangan mengenai Ketentuan serta Tata cara Pelaksanaannya.

Dalam prakteknya, modal merupakan salah satu faktor utama dalam mengembangkan usaha, karena dengan semakin besarnya modal yang dimiliki akan lebih memperluas usaha dan jaringan usaha. Namun dalam kenyatannya modal merupakan kendala utama, khsususnya kalangan usaha kecil dan menengah.

Sulitnta pelaku usaha kecil dalam mendapatkan pendanaan dari bank dikarenakan Bank dalam setiap pemberian kreditnya kepada calon nasabah menerapkan prosedur administrasi standar bank. Prosedur standar ini diberlakukan guna mencegah terjadinya kredit bermasalah dikemudian hari.

Selain itu dalam upaya pembiayaan mengantisipasi kredit bermasalah tersebut Bank sebagai salah satu lembaga pembiayaan dalam setiap pemberian kredit juga memberlakukan prinsip kehati - hatian yang meliputi adanya data yang lengkap bagi setiap calon nasabahnya. Selain itu Bank juga harus mengetahui tujuan dan penggunan kredit yang akan diajukan. Bank juga akan melihat dan menilai apakah usaha yang menggunakan kredit dari bank itu memiliki prospek yang menguntungkan serta yang paling penting adanya kemampuan pengembalian kredit dari debiturnya.

Oleh karena itu, Untuk mengatasi kendala keuangan, khususnya bagi kalangan UMKM maka peranan perusahaan jasa yang menyediaankan permodalan selain bank memiliki peran yang sangat penting dalam memberikan bantuan dana yang diperlukan. Ini dikarenakan fungsi utama perusahaan keuangan adalah menyediakan Pembiayaan dana / modal bagi perusahaan lain yang memerlukan dana / modal.

Dalam praktek perbankan, kegiatan dalam bidang keuangan biasanya dilakukan oleh perusahaan yang dalam kegiatnnya dibidang keuangan yang dikenal dengan lembaga keuangan. Fungsi utama dari lembaga keuangan ini adalah menghimpun dana yang berasal masyarakat disamping itu juga memberikan pembiayaan modal pada suatu bidang usaha.

Dalam undang-undang dapat diartikan bahwa yang dimasud dengan Perbankan merupakan suatu perusahaan yang aktifitasnya dalam bidang keuangan yang memiliki fungsi sebagai penghimpun dan menyalurkan dana kepada masyarakat, baik itu orang perorangan kelompok orang maupun badan hukum. ${ }^{2}$."

Sedangkan petunjuk teknis dari undang - undang itu adalah peraturan yang dikeluarkan oleh Presiden RI mengenai Lembaga pembiayaan. Secara umum Lembaga pembiayaan dapat diartikan sebagai suatu kegiatan yang dilakukan oleh badan usaha yang aktifitasnya dalam bidang pembiayaan. Pembiayaan tersebut dapat berupa penyediaan dana maupun barang sebagai modal bagi pelaku usaha yang membutuhkannya ${ }^{3}$

Dalam prakteknya, Lembaga pembiayaan dalam mejalankan fungsinya dilaksaksanakan oleh suatu perusahaan yang dikenal dengan perusahaan pembiayaan. Secara umum perusahaan pembiayan merupakan suatu usaha yang khusus didirikan guna melakukan sewa guna usaha, maupun Anjak Piutang, serta Pembiayaan Konsumen, selain itu juga usaha Kartu Kredi"4.

Secara prakteknya kegiatan yang dilakukan Lembaga keuangan dapat diklasifikasikan kedalam 3 (tiga) bagian, yaitu : Lembaga yang bergerak dalam bidang keuangan dalam bentuk bank, lembaga keuangan bukan bank dan Lembaga - Lembaga pembiayaan lainya, ${ }^{5}$ salah satu lembaga pembiayaan yang meliputi bidang usaha yang di jalankan oleh perusahaan pembiayaan adalah perusahaan modal ventural ( $p m v)$.

Kehadiran pmv membawa harapan baru bagi perkembangan dunia bisnis di Indonesia terutama bagi kalangan dunia usaha kecil dan menengah, karena diharapkan dapat menawarkan kemudahan dan alternatif yang lebih efektif dan efisien dalam pengembangan dunia usaha.

Walaupun pmv sebagai salah satu lembaga pembiayaan yang belum begitu banyak dikenal dikalangan pengusaha namun kehadirannya dapat menjadi alternatif dalam mengatasi permasalahan kekurangan modal usaha khususnya usaha kecil mikro dan menengah. Selain itu disamping penyediaan modal yang diberikan juga adanya

\footnotetext{
${ }^{1}$ A. Toni Prasetiantono, Ekonomi Rakyat dan Pasar Bebas, (Yogyakarta: Pustaka Pelajar, 2000), hlm. 27

${ }^{2}$ Undang-Undang Republik Indonesia Nomor 10 Tahun 1998 Tentang Perubahan Atas UU No. 7 Tahun 1992 Tentang Perbankan

${ }^{3}$ Peraturan Presiden Nomor 9 Tahun 2009 Tentang Lembaga Pembiayaan

${ }^{4}$ Ibid

${ }^{5}$ Abdul Kadir Muhammad dan Rilda Muniarti, Lembaga Keuangan dan Pembiayaan, (Bandung: PT. Citra Adhitya Bakati, 2004), hlm. 17
} 
pendampingan manajemen dari perusahaan modal ventura serta adanya sistem pengembaliaan (repayment) yang cukup fleksibel, hal ini memberikan nilai tambah tersendiri bagi pmv dari lembaga pembiayaan lainya.

Dari data yang diperoleh, Industri modal ventura menunjukkan pertumbuhan signifikan di tahun ini. Ini tercermin dari kinerja pembiayaan dan rasio nonperforming financing $(N P F)$ yang membaik.

Berdasarkan data Otoritas Jasa Keuangan (OJK), sampai Oktober 2019, pembiayaan atau penyertaan modal ventura tercatat $\operatorname{Rp~8,13~triliun.~Jumlah~itu~tumbuh~20\% ~dari~Oktober~tahun~lalu~yakni~Rp~6,77~triliun~} 6$

Portofolio pembiayaan masih didominasi kegiatan pembiayaan bagi hasil sebesar $\mathrm{Rp}$ 6,25 triliun, lalu mengikuti penyertaan saham Rp 1,38 triliun dan sisanya dari obligasi konversi Rp 484 miliar. Mayoritas pembiayaan modal ventura untuk menopang sektor perdagangan, restoran dan hotel, kemudian diikuti jasa pengakutan bisnis serta sektor pertanian, perikanan dan kehutanan.

Dengan meningkatnya jumlah perusahaan modal ventura yang telah terdaftar di Otoritas Jasa Keuangan (OJK), semakin meningkatkan pembiayaan industri ventura di bulan Juli 2018. Otoritas Jasa Keuangan (OJK) mencatat bahwa sampai dengan Juli 2018 ini industri modal ventura yang terdaftar di OJK mengalami penambahan jumlah perusahaan yang cukup banyak. Tercatat ada sekitar 65 perusahaan modal ventura yang telah terdaftar secara resmi di OJK.

Hal ini mengalami peningkatan sebesar $20 \%$ bila di bandingkan dengan nilai kenaikan pada tahun sebelumnya. Demikian jumlah perusahaan pasangan usaha (PPU) juga mengalami kenaikan 6\% dari tahun sebelumnya menjadi 10.738 ppu. Lain halnya dengan nilai total laba (rugi) perusahaan modal ventura yang justru mengalami penurunan sebesar $22,4 \%$ dari tahun sebelumnya menjadi ${ }^{7} 30$ milyar rupiah.

Dari total Perusahaan Pasangan Usaha (PPU) yang memperoleh penyertaan modal dari PMV adalah 10.738 PPU yang terdiri dari PMV swasta nasional berjumlah 714 PPU, PMV patungan berjumlah 58 PPU. Dengan demikian dari data secara nasional dapat diperoleh bahwa jumlah PPU yang mendapatkan penyertaan modal dari PMV sebanyak 10.738 PPU $^{8}$.

Dalam hal penyertaan modalnya, Perusahan Modal Ventura dalam prakteknya membagi penyertaan modal tersebut menjadi tiga klasifikasi, yaitu ${ }^{9}$ :

1. Berupa Penyertaan modal oleh PMV secara langsung kedalam Perusahaan Pasangan Usahanya yang dibiayai (investee Company)

2. PMV dapat melakukan Pembelian saham PPU yang dibiayai

3. Obligasi Konversi yang memiliki hak opsi untuk ditukarkan dengan saham biasa PPU yang dibiayai.

Penyertaan langsung adalah modal oleh PMV berupa pengambilan sejumlah saham tertentu dari PPU. Saham tersebut biasanya dari saham - saham fortofolio yaitu saham _saham yang belum diambil bagian dan disetor oleh pemegang saham lainnya. Penyertaan modal dalam bentuk saham dapat dilakukan dengan cara: pertama dengan Mendirikan suatu usaha bersama dalam bentuk Perseroan Terbatas, selanjutnya dengan cara saham dalam simpanan (forto folio) PPU.

Sedangkan bentuk penyertaan modal secara tidak langsung tersebut dapat berupa: ${ }^{10}$

1. Obligasi Konversi, yaitu bentuk pembiayaan yang pada awalnya dilakukan dalam bentuk hutang piutang yang nantinya akan dikonversi menjadi saham.

2. Partisipasi terbatas / bagi hasil, yaitu instrumen pembiayaan yang dilakukan dalam hal usaha yang akan dibiayai tidak berbentuk Badan Hukum atau syarat - syarat yang harus dipenuhi untuk penyertaan langsung belum atau dipenuhi oleh PPU, Bentuk ini menekankan pada pola bagi hasil dari keuntungan yang diperoleh dari usaha.

Namun dalam prakteknya, jenis pembiayaan yang dilakukan melalui PMV terbagi menjadi 2 (dua) yaitu ${ }^{11}$ :

1. Dalam bentuk penyertaan modal

2. Dalam bentuk pemberian pinjaman dengan pola bagi hasil seperti halnya pinjaman/kredit bank

Apabila pembiayaan dilakukan dalam bentuk penyertaan equity maka PMV tidak perlu meminta jaminan kepada PPU, sebaliknya apabila pembiayaan diberikan dalam bentuk kredit/pinjaman maka PMW harus meminta jaminan dari PPU.

${ }^{6}$ https://keuangan.kontan.co.id/news/pembiayaan-modal-ventura-tumbuh-20-hingga-oktober-2018, diakses tanggal 20 Februari 2020

7 ibid

${ }^{8}$ Sumber : www.depkeu.go.id=kinerjaventura,diakses, 7 Maret 2020

${ }^{9}$ Abdul Kadir Muhammad dan Rilda Muniarti, Op.Cit, hlm. 86

10 Andi Maradang Mackulau, Aspek Hukum Pembiayaan Dengan Modal Ventura,(Makalah Bahan Pelatihan Training Legal Officer PMV, 2001), hlm. 26

${ }^{11}$ Hasannuddin Rahman, Segi Hukum Modal Ventura, Alternatif Pemikiran Kearah Modal Ventura yang Sesuai Dengan Kultur Bisnis di Indonesia, (Bandung : PT. Citra Aditya Bakti, 2012), hlm. 157 
Biasanya dalam kontrak pembiayaan dijelaskan bahwa Sebagai lembaga pembiayaan terikat dengan adanya sanksi penghentian kegiatan atau pencabutan izin bagi pmv yang melakukan pembiayaan yang bertentengan dengan surat Keputusan Menteri Keuangan yang mengatur mengenai ketentuan maupun mengenai tata cara Lembaga pembiayaan dalam melakukan kegiatanya, yang kemudian peraturan itu diubah dengan KepMenKeu RI No. 468/KMK.017/1955 Tanggal 3 Oktober 1995.

Dalam prakteknya pembiayaan yang dilakukan oleh pmv hanya terbatas pada pemberian kredit dengan pola bagi hasil. Sedangkn dalam mendapatkan pembiayaan dari pmv, syarat yang harus dipenuhi oleh calon perusahaan pasangan usaha $(C P P U)$ antara lain :

1. CPPU harus mengajukan permohonan secara tertulis dengan melampirkan proposal kegiatan usaha yang akan dibiayai dengan membuat laporan keuangan mengenai kondisi ysaha yang terakhir dan perkiraan kondisi usaha yang akan dating

2. CPPU harus melengkapinya dengan aspek legalitas atas usaha yang akan dibiayai misalnya hal yang berkaitan dengan masalah - masalah perizinan dan jaminan.

3. Menyampaikan semua dokumen yang berkaitan dengan usaha yang dimaksud untuk selanjutnya dievaluasi oleh PMV.

Setelah syarat diatas terpenuhi maka pmv dalam penyertaan modalnya pada beberapa calon Perusahaan Pasangan Usaha (CPPU) terlebih dahulu membuat kesepakatan yang dituangkan dalam bentuk perjanjian tertulis (kontrak) yang berisi beberapa kesepakatan, diantaranya mengenai jangka waktu divestasi atau selama jangka waktu kontrak, Perusahaan Pasangan Usaha dapat mengembalikan modal dengan cara mencicil setiap bulan yaitu angsuran modal dan bunga, Disamping adanya kewajiban untuk memberikan jaminan kepada pmv . Jaminan dimaksud bertujuan sebagai factor pengaman (security factor) atas resiko yang mungkin terjadi apabila PPU melakukan wanprestasi dikemudian hari.

Wanprestasi dimaksud adalah jika salah satu pihak terutama perusahaan pasangan usaha Ketika didalam pelaksanaan perjanjiannya tidak melakukan kewajiban sebagaimana yang tertuang dalam isi kontrak.

Secara umum, wanprestasi yang dapat dialkukan oleh para pihak dapat berupa para pihak tidak melaksanakan sesuai denga nisi perjajian, melaksanakan suatu perbuatan tapi tidak sesuai denga nisi kontrak yang telah disepakati, salah satu pihak terlambat dalam melaksanakan kewajibannya sebagaimana yang tertuang dalam isi kontrak serta melakukan sesuatu yang tidak ada dalam isi kontrak $^{12}$.

Namun demikian, adakalanya PPU dalam memenuhi prestasinya sebagaimana kesepakatan dalam kontrak pembiayaan tidaklah sebagaimana yang diharapkan, hal inilah yang dapat menyebabkan terjadinya wanprestasi yang dilakukan oleh PPU.

\section{METODE}

Salah satu ciri dari kegiatan penelitian ilmiah adalah menggunakan metode yang logis dan sistematis. Ditinjau dari asal katanya metodelogi berasal dari Bahasa Yunani, yaitu methodus dan logos yang berarti cara kerja untuk memahami obyek sasaran yang bersangkutan ${ }^{13}$. Penelitian ini menggunakan metode hukum normatif yaitu penelitian yang dilakukan melalui study Pustaka atau dengan kata lain ini penelitian menggunakan studi dokumen, dengan mempergunakan bahan hukum sekunder seperti peraturan perundang -undangan, keputusan pengadilan, teori hukum, dan juga pendapat para ahli hukum ${ }^{14}$.

\section{HASIL DAN PEMBAHASAN}

\section{Penyelesaian Sengketa Kontrak PMV Dengan PPU Yang Melakukan Wanprestasi}

Istilah "modal ventura" merupakan terjemahan dari terminologi Bahasa Inggris yaitu "ventura capital" Ventura adalah merupakan serapan dari venture yang berarti usaha yang mengandung resiko. Modal Ventura adalah modal yang ditanamkan pada usaha yang mengandung resiko.

Dalam Dicionory of business terms, dikatakan modal ventura adalah: "sumber pembiayaan dari suatu perusahan yang melibatkan resiko invenstasi namun juga dapat memberikan keuntungan besar dari investasi modal tersebut"15.

Sedangkan keputusan Menteri keuangan memberikan pengertian lembaga modal vntura merupakan suatu usaha yang melakukan penyertaan modal kedalam suatu perusahaan dalam jangka waktu tertentu. Dalam penyertaan modalnya kepada perusahan pasangan usahanya, pmv diisyaratkan dalam melakukan penarikan modalnya tidak boleh melebihi jangka waktu 10 tahun.

\footnotetext{
${ }^{12}$ Djoko Trianto, Hubungan Kerja di Perusahaan Jasa Konstruksi, (Bandung : Mandar Maju, 2004), hlm. 61

${ }^{13}$ Soerjono Soekanto, Pengantar Penelitian Hukum, (Jakarta : Press UI, 1986), hlm. 15

14 Johhnny Ibrahim, Teori dan Metode Penelitian Hukum Normatif, (Jakarta : Bayu Madia, 2016), hlm. 45

${ }^{15}$ Munir Fuady, Hukum Tentang Pembiayaan Dalam Teori dan Praktek, (Bandung : Citra Aditya Bakti, 2002), hlm. 109
} 
Dalam dunia bisnis, adalah hal yang wajar jika setiap orang yang menjalankan usaha bisnisnya menghendaki segala sesuatu berjalan dengan baik tanpa ada masalah. Akan tetapi dalam kenyataan usaha bisnis tidak selamanya dapat berjalan dengan lancar. Tidak heran jika dalam berbisnis tidak hanya masalah yang muncul tapi juga dapat menimbulkan sangketa.

Dalam melakukan usaha bisnisnya, PMV pun tak lepas dari permasalahan dengan PPUnya yang melakukan wanprestasi, hal ini bahkan dapat menimbulkan sangketa. Oleh karena itu untuk mengatasi masalah yang mungkin saja dapat menimbulkan kerugian, maka PMV dalam setiap kesepakatan kontrak penyertaan modalnya selalu disertai dengan jaminan. Hal ini merupakan penyertaan modal ventura "ala” Indonesia.

Menurut Richard Burton S, di Indonesia dalam prakteknya ada 3 (tiga) bentuk pembiayaan yang dapat dilaksanakan oleh modal ventura yaitu ${ }^{16}$ :

1. Convensional Ioan, pinjaman jenis ini biasa diberikan tanpa jaminan dan bisa pula disertai dengan jaminan.

2. Conditional Ioan, dalam model ini modal ventura turut menikmati laba, namun jika proyeknya mengalami keruggian maka modal ventura ikut juga mengalami kerugian.

3. Equity investmen, PMV hanya menyertakan sahamnya terhadap perusahaan yang baru berdiri sehingga diantara keduanya terjalin kerjasama dibudang manajemen.

Pada mulanya penyertaan modal kepada PPU oleh PMV diberi peluang untuk tidak menyertakan jaminan sesuai dengan karakteristik PMV itu sendiri, namun dalam kenyataannya PPU dalam pengembalian pinjamannya banyak melakukan ingkar janji/wanprestasi dengan berbagai alasan sehingga membuat PMV mengalami kerugian baik dari segi permodalan maupun waktu yang banyak tersita dalam mengurusi PPU yang wanprestasi.

Oleh karena itu dalam perkembangannya klausul yang terdapat dalam isi kontrak yang dibuat oleh PVM mewajibkan PPU untuk menyertakan jaminan, hal ini dimungkinkan sebagai faktor pengaman (security factor) dalam setiap penyertaan modalnya. Guna menentukan apakah PPU telah melakukan wanprestasi atau tidak maka terlebih dahulu akan dianalisa isi kontrak pembiayaan yang dibuat oleh PVM dengan PPU khususnya pasal-pasal yang berkaitan dengan hak dan kewajiban PPU, ketentuan mengenai bentuk-bentuk wanprestasi yang dilakukan PPU serta ketentuan isi kontrak tentang cara penyelesaian sengketa antara kdua belah pihak.

Menurut Salim HS, ${ }^{17}$ didalam isi kontrak atau pejanjian yang perjanjian yang dibuat para pihak paling tidak memiliki 2 fungsi. Baik itu berupa fungsi yuridis maupun fungsi ekonomis.

Fungsi tersebut mengandung arti bahwa, kontrak yang dibuat para pihak itu selain dapat memberikan kepastian hukum bagi para pihak yang melakukan perjanjian juga dengan adanya kontrak itu dapat meningkatkan fungsi hak milik sebagai sumber daya dari nilai yang lebih rendah menjadi penggunaan yang semakin tinggi. yaitu ${ }^{18}$ :

Lebih lanjut menurutnya bahwa fungsi utama dari kontrak adalah fungsi yuridis, fungsi yuridis dari kontrak

1. untuk mengatur hak dan kewajiban para pihak;

2. untuk mengamankan transaksi bisnis;

3. untuk mengatur tentang pola penyelesaian sengketa yang timbul antara kedua belah pihak.

Mengingat dalam setiap transaksi bisnis yang buat para pihak harus dituangkan dalam perjanjian atau kontrak, maka dalam setiap perjanjian atau kontrak yang dibuat haruslah memenuhi syarat - syarat tertentu khususnya sebagaimana yang diatur dalam peraturan perundang - undangan yang berlaku, terutama sebagaimana diatur dalam Kitab Undang - undang Hukum Perdata (Pasal 1320 dan 1338 KUH Pdt).

Hal inipun tak terkecuali dengan kontrak pembiayaan yang dibuat antara PMV dengan Perusahaan Pasangan Usaha. Dimana dalam isi kontrak mengatur hak dan kewajiban para pihak.

Dalam kenyataan terdapat banyak hal-hal yang menjadi kewajiban bagi Perusahaam Pasangan Usaha yang harus dipenuhi, hal ini dalam rangka keyakinan PMV untuk pemenuhan kewajiban pengembalian pemberian bantuan modal tersebut.

Hal seperti ini oleh PMV dimasukkan sebagai materi pasal-pasal dalam kontrak, seperti laporan atas usaha dan penggunaan modal yang telah diterimanya.

Hal-hal yang lazim diperjanjikan yang dituangkan dalam isi kontrak pembiayaan modal ventura, meliputi :

a. Suku bunga atau besarnya prosentase bagi hasil modal ventura yang diberikan;

b. Jangka waktu penggunaan modal ventura oleh Perusahaan Pasangan Usaha;

c. Cara-cara pengembalian dari PPU kepada PMV ;

d. Convenant yang harus dipenuhi oleh PPU baik sebelum maupun setelah pencarian dana oleh PMV ;

\footnotetext{
${ }^{16}$ Richard Borton S, Aspek Hukum Dagang Dalam Bisnis, (Jakarta : Rineka Cipta, 2003),

${ }^{17}$ Salim HS dkk, Perancangan Hukum Kontrak dan MoU, (Jakrta : Sinar Grafika, 2007),

hlm. 24

${ }^{18} \mathrm{I}$ bid, hlm. 25
}

hlm. 106 
e. Biaya yang harus dikeluarkan dan menjadi tanggungan bagi PPU

Karena kontrak tersebut telah dibuat dan telah memenuhi syarat sahnya kontrak (Pasal $1320 \mathrm{KU}$ Pdt), maka kontrak tersebut adalah sah dan mengikat bagi para pihak. Kontrak yang dibuat secara sah tersebut berlaku sebagai undang-undang bagi mereka yang membuatnya, sehingga adanya kewajiban untuk dilaksanakan dengan itikad baik (Pasal 1338 KU Pdt).

Bagi pihak yang tidak melaksanakan kewajibannya sebagaimana yang dituangkan dalam kontrak, maka dapat dikatakan telah melakukan tindakan wanprestasi. Karena kewajiban-kewajiban bagi Perusahaan Pasangan Usaha adalah merupakan suatu prestasi.

Prestasi adalah apa yang menjadi hak keditur dan menjadi kewajiban bagi debitur, adapun yang dimaksud dengan prestasi yaitu baik dalam bentuk melakukan penyerahan sesuatu, melakukan suatu perbuatan maupun tidak melakukan sesuatu perbuatan.

Selain itu, Subekti ${ }^{19}$ memberikan pengertian prestasi yang ada dalam kontrak adalah pelaksanan perjanjian tertulis yang dilaksanakan para pihak yang terikat dalam perjanjian itu dan dilaksanakan sesuai dengan isi kontrak.

Apabila menurut pertimbangan PT Sarana Sumatera Selatan Ventura dianggap perlu guna memenuhi ketentuan Pasal 224 HIR atau Pasal 258 Rbg. Berdasarkan perjanjian ini dapat menetapkan pengakuan utang perusahaan pasangan usaha dalam suatu perjanjian tersendiri termasuk penegasan atas jaminan-jaminan yang telah di berikan besertan segala perubahannya dengan syarat-syarat dan ketentuan-ketentuan yang di setujui oleh PMV dan tidak bertentangan ketentuan-ketentuan dalam hukum perjanjian.

Dari kontrak tersebut diketahui bahwa pihak ppu telah mengakui secara sah adanya hutang pada PMV, terhadap pengakuan hutang ini PMV telah menerima baik pengakuan utang tersebut. Penetapan besarnya jumlah hutang ini termasuk kewajiban pembayaran bagi hasil yang telah jatuh tempo, juga termasuk pengakuan terhadap jaminanjaminan yang telah di berikan.

Dalam kontrak pembiayaan usaha kecil pihak perusahaan pasangan Usaha selain dari beberapa kewajiban yang akan dibebankan kepadanyan, juga telah menyatakan beberapa kesanggupan yang harus dilaksanakan. Sebagaimana yang diatur dalam kontrak pembiayaan.

Perusahaan Pasangan Usaha dalam menjalankan usahanya akan melaksanakan penatausahaan diadministrasi dan penyediaan tenaga stap yang diperlukan sehubungan dengan pelaksanaan perjanjian ini, termasuk penatausahaan administrasi proyek pengadaan/pembelian barang;

Perusahaan pasangan usaha menanggung semua biaya yang timbul sehubungan dengan penatausahaan administrasi dan pelaksanaan perjanjian ini termasuk pajak-pajak yang tertuang dan timbul serta wajib dibayarkan oleh perusahaan pasangan usahan selama berlangsungnya perjanjian undangan maupun doktrin hukum serta prinsip hukum yang berlaku di wilayah hukum Indonesia.

Kesanggupan-kesanggupan yang dikemukakan oleh perusahaan pasangan usaha seperti melaksanakan penata usahaan, penyediaan stap, pembayaran pajak, pengembalikan dan membayar semua kewajiban yang timbul dalam perjanjian. Juga peryataan kesanggupan untuk membayar semua fasilitas dana yang telah diterimannya, serta akan membayar semua keuntungan bagi hasil dalam waktu yang telah ditentukan dalam kontrak.

Bila pihak perusahaan pasangan usaha tidak kelaksanakan kewajibannya, melaksanakan kewajibannya tetapi terlambat atau melaksankan kewajiban tidak sesuai dengan yang diperjanjikan yang tgelah ditentukan dalam kontrak maka dapat dikatakan melakukan kelalaian atau wanprestasi.

Dalam prakteknya kontrak pembiayaan, Pernyataan lalai para pihak telah sepakat untuk mengesampingkan ketentuan hukum yang diatur dalam Pasal 1266-1267 KUH Perdata sehingga pelaksanaan tidak diperlakukan lagi keputusan, penaetapan, izin, maupun kekuasaan dari pengadilan.

Terhadap pihak Perusahaan Pasangan Usaha yang dilakukan tindakan wanprestasi sebagaimana dikemukakan diatas, maka pihak PMV akan melakukan peringatan yang tujuannya agar pihak Perusahaan Pasangan Usaha akan melakukan kewajibannya.

Setelah jangka waktu 8 (delapan) hari Perusahaan Pasangan Usaha tidak memenuhi kewajban tersebut kepada perusahaan modal Ventura akan mengirimkan peringatan (somasi) kedua.

Setekah jangka waktu 8 (delapan) hari sejak peringatan (somasi) kedua, Perusahaan Pasangan Usaha tidak memenuhi kewajibannya kepada PMV maka akan mengirimkan peringatan (sosmasi) ketiga;

Maka setelah jangka waktu 8 (delapan) hari sejak peringatan (somasi) ketiga, Perusahaan Pasangan Usaha tetap tidak memenuhi kewajibannya, maka PMV dapat memutuskan perjanjian ini secara sepihak dengan mengenyampingkan Pasal 1266-1267 KUH Perdata ${ }^{20}$.

${ }^{19}$ Subekti, Pokok - pokok Hukum Perdata, (Jakarta : PT. Intermasa, 1986), hlm. 120

${ }^{20}$ Pasal 1226 KUH Pdt menjelaskan bahwa dalam perjanjian yang timbal balik perlu dicantumkan syarat-syarat batal suatu perjanjian dan tiap-tiap pembatalan perjanjian harus dimintakan putusan Hakim 
Dengan terjadinya kelalain atau wanprestasi yang dilakukan oleh PPU dan telah beberapa kali diberikan peringatan. Pengakhiran perjanjiana ini kerena PPU tidak melaksanakan perjanjian karena kelalaian dan/atau kesalahan tidak menghilangkan hak PMV untuk menuntut ganti kerugian sebesar seluruh jumlah fasilitas pembiayaan dan bagi hasil yang tertuang serta baiaya-biaya lainnya yang akan timbul akibat kelalain tersebut. Dalam hal terjadinya sengketa antara PMV dengan PPU harus diselesaikan makanisme yang telah diatur dalam kontrak perjanjian.

Adapun cara penyelesaian sengketa kontrak ini pada perjanjian pembiayaan PMV dengan PPU biasanya dilakukan dengan cara sebagai berikut:

1. Semua sengketa yang akan timbul dikemuadian hari antara pihak dan/atau antara para pihak dalam perjanjian ini dengan pihak ketiga mengenai perjanjian ini dan/atau pelaksanaannya, para pihak telah sepakat untuk menyelesaikan dengan mekanisme Non Litigasi (alternative disputes resolution) dan hasilnya akan dibuat secara tertulis;

2. Mekanisme penyelesaian sebagaimana dimaksud, apabila tidak tercapai dalam waktu 60 (enam puluh) hari, maka para pihak telah sepakat untuk memilih domisili hukum di kantor kepaniteraan pengadilan Negeri, atau dengan tidak mengurangi hak PMV mengajukan tuntutan/gugatan hukum kepada perusahaan pasangan usaha melalui kantor pelayanan Piutang dan Lelang Negara $(K P 2 L N)$.

Dari ketentuan diatas jelas bahwa penyelesaian sengketa antara PMV dengan PPU diutamakan dengan Non Litigasi atau penyelesaian di luar pengadilan. akan tetapi jika penyelesaian melalui mekanisme Non Litigasi ini mengalami kegagalan, maka alternative lainnya diselesaikan melalui melalui pengadilan.

Pihak perusahaan pasangan usaha ( $р р и)$ dapat dikatakan melakukan kelalaian bila mana ia tidak memenuhi kewajiban sama sekali, atau terlambat memenuhi kewajibanya, atau memenuhi kewajibannya tetapi tidak sesuai dengan apa yang telah di perjanjikan.

Hal kelalaian atau wanprestasi pihak perusahaan pasangan usaha ini harus dinyatakan terlebih dahulu secara resmi, yaitu dengan memberikan somasi atau peringatan bahwa perusahaan pasangan usaha dikehendaki untuk melakukan pembayaran baik angsuran pokok maupun angsuran bagi hasil.

Menurut Suyud Margono ${ }^{21}$ dalam bukunya berjudul Alternatif Dispute Resolution \& Arbitrase, proses pelembagaan dan Aspek Hukum, yang menjelaskan bahwa penyelesaian sengketa bisnis dapat diselesaikan secara alternative terdiri dari negosiasi, mediasi, konsiliasi, dan arbitrase.

Negosiasi secara umum dapat diartikan "proses consensus yang digunakan para pihak untuk memperoleh kesepakatan diantara mereka".

Sedang Jackman mengarti negosiasi merupakan terjadinya pertemuan dua orang atau lebih yang pada mulanya memiliki pandangan yang berbeda akan suatu masalah namun pada akhirnya memiliki satu kesepakatan terhadap masalah tersebut ${ }^{22}$.

Dalam proses ini para pihak berhadapan langsung dalam mendiskusikan permasalahan yang mereka hadapi dengan cara kooperatif dan saling terbuka. proses tawar-menawar dengan jalan berunding untuk member atau menerima guna mencapai kesepakatan bersama antara satu pihak kepada pihak yang lain. dengan demikian bahwa dalam negosiasi terdapat keinginan para pihak untuk menyelesaikan permasalahan yang sedang mereka hadapi dengan tujuan mendapat kesepakatan yang saling menguntungkan. Dalam negosiasi ini terdapat beberapa prinsip penting yaitu:

1. Negosiasi melibatkan dua pihak atau lebih;

2. Pihak-pihak harus membutuhkan keterlibatan satu sama lain dalam mencapai hasil yang diinginkan bersama;

3. Pihak-pihak yang bersangkutan, setidak-tidaknya pada awalnya menganggap negosiasi sebagai cara yang lebih memuaskan untuk menyelesaikan perbedaan mereka dibandingkan dengan metode-metode lain;

4. Masing-masing pihak harus beranggapan bahwa ada kemungkinan untuk membujuk pihak lain untuk memodifikasi posisi awal mereka;

5. Setiap pihak harus mempunyai harapan akan sebuah hasil akhir yang mereka terima, dan suatu konsep tentang seperti apakah hasil akhir itu;

6. Masing-masing pihak harus mempunyai suatu tingkat kuasa atas kemampuan pihak lain untuk bertindak;

Proses negosiasi itu sendiri pada dasarnya merupakan salah satu interaksi di antara orang-orang terutama antar komunikasi lisan yang langsung, walaupun kadang-kadang dengan elemen tertulis yang penting.

Di samping negoisasi, penyelsaian sengketa bisnis dapat juga di tempuh melalui mediasai. Mediasi adalah ${ }^{23}$ proses perdamaian yang dilakukan para pihak yang bersengketa dan menyerahkan penyelesaiannya kepada mediator.

\footnotetext{
${ }^{21}$ Suyud Margono, ADR (Alternatif Disfute Resulation \& Arbitrase, Proses Pelembagaan dan Aspek Hukum, ( Jakarta : GhaliaIndonesia, 2000), hlm. 28

${ }^{22}$ Jacman, A, How To Negotiate : Teknik Sukses Bernegosiasi, (Jakrta : Erlangga, 2005), hlm. 8

${ }^{23}$ Abdurrasyid, H. Priyatna, Arbitrase dan Alternatif Penyelesaian Sengketa, ( Jakarta : PT. Fikahati, 2001 ), hlm 42
} 
Mediasi sering disebut juga proses di mana para pihak dengan bantuan seorang atau beberapa orang secara sistematis menyelsaikan permasalahan yang di sengketakan untuk mencari alternative dan mencapai penyelsaian yang tepat mengakomodisi kebutuhan para pihak.

Dalam prakteknya penyelsaian yang dilakukan Oleh PMV terhadap PPU yang melalukan wanprestasi biasanya diselesaikan dengan cara negosiasi antar para pihak. Apabila tidak tercapai kesepakatan maka pihak PMV akan menyelesaikannya melalui Kantor Pelayanan dan Piutang Negara $(K P 2 L N)$ guna mengambil pelunasan dari jaminan yang di serahkan oleh PPU pada saat penanda tangan kontrak. Apabila masih terdapat sengketa yang belum atau dapat diselesaikan maka PMV akan membawa perkara ini melaui proses hukum di Pengadilan.

\section{SIMPULAN}

Dari uraian latar belakang dan hasil pembahasan maka dapat disimpulkan bahwa Dalam hal terjadi sengketa, Sebagaimana ketentuan isi kontrak dimana para pihak sepakat dalam menyelesaikan setiap sengketa yang terjadi lebih mengutamakan mekanisme non litigasi atau dengan penyelesaian sengketa alternative (alternative dispute resolution), baik secara negoisasi, mediasi, konsiliasi maupun arbitrase, dimana hasil kesepakatan tersebut harus dibuat secara tertulis.

Bila mana penyelesaian sengketa tidak tercapai kesepakatan, maka dalam waktu 60 (enam puluh) hari para pihak sepakat untuk menyelesaikan sengketa tersebut melalui jalur litigasi dan sepakat untuk memilih domisilih hukum dikantor kepaniteraan Pengadilan Negeri atau dengan tidak mengurangi hak PMV untuk mengajukan tuntutan/gugatan hukum kepada PPU melalui kepaniteraan Pengadilan Negeri lainnya yang berwenang atau melalui Kantor Pelayanan Piutang Dan Lelang Negara (KP2LN).

\section{DAFTAR PUSTAKA \\ Buku}

Abdul Kadir Muhammad dan Rilda Muniarti, Lembaga Keuangan dan Pembiayaan, 2004: PT. Citra Adhitya Bakati, Abdurrasyid, H. Priyatna, Arbitrase dan Alternatif Penyelesaian Sengketa, Jakarta: PT. Fikahati, 2001

Andi Maradang Mackulau, Aspek Hukum Pembiayaan Dengan Modal Ventura, Jakarta, Makalah Bahan Pelatihan Training Legal Officer PMV, 2001

A. Toni Prasetiantono, Ekonomi Rakyat dan Pasar Bebas, Yogyakarta: Pustaka Pelajar, 2000

Djoko Trianto, Hubungan Kerja di Perusahaan Jasa Konstruksi, Bandung: 2004, Mandar Maju

Hasannuddin Rahman, Segi Hukum Modal Ventura, Alternatif Pemikiran Kearah Modal Ventura yang Sesuai Dengan Kultur Bisnis di Indonesia, Bandung: PT. Citra Aditya Bakti, 2012

Jacman, A, How To Negotiate: Teknik Sukses Bernegosiasi, Jakarta: Erlangga, 2005

Johnny Ibrahim, Teori dan Metode Penelitian Hukum Normatif, Jakarta: Bayu Media, 2016

Munir Fuady, Hukum Tentang Pembiayaan Dalam Teori dan Praktek, Bandung: 2002, Citra Aditya Bakti, Bandung

Richard Borton S, Aspek Hukum Dagang Dalam Bisnis, Jakarta: Rineka Cipta, 2003

Salim HS dkk, Perancangan Hukum Kontrak dan MoU, Sinar Grafika

Soerjono Soekanto, Pengantar Penelitian Hukum, Jakarta: Press UI, 1986

Subekti, Pokok - pokok Hukum Perdata, Jakarta, PT. Intermasa, 2008

Suyud Margono, ADR (Alternatif Disfute Resulation \& Arbitrase, Proses Pelembagaan dan Aspek Hukum, Jakarta: Ghalia Indonesia, 2000

\section{Peraturan Perundang - undangan}

Kitab Undang - Undang Hukum Perdata

Undang-undang Republik Indoneaia Nomor 20 Tahun 2008 Tentang UMKM

Undang-undang Republik Indonesia Nomor 10 Tahun 1998 Tentang Perubahan Atas UU No. 7 Tahun 1992 Tentang Perbankan

Peraturan Preseden Nomor 9 Tahun 2009 Tentang Lembaga Pembiayaan

Peraturan Menteri Kuangan Nomor 18/PMK.010/2012 Tentang Perusahaan Modal Ventura

\section{Internet}

https://keuangan.kontan.co.id/news/pembiayaan-modal-ventura-tumbuh-20-hingga-oktober-2018

www.depkeu.go.id=kinerjaventura, 2019 